\title{
Article \\ Ready-to-Eat Sandwiches as Source of Pathogens Endowed with Antibiotic Resistance and Other Virulence Factors
}

\author{
Stefania Camellini (D), Ramona Iseppi *(D), Carla Condò and Patrizia Messi (D) \\ Department of Life Sciences, University of Modena and Reggio Emilia, Via G. Campi 103/287, \\ 41125 Modena, Italy; stefania.camellini@unimore.it (S.C.); carla.condo@unimore.it (C.C.); \\ patrizia.messi@unimore.it (P.M.) \\ * Correspondence: ramona.iseppi@unimore.it; Tel.: +39-059-205-5469
}

check for updates

Citation: Camellini, S.; Iseppi, R.; Condò, C.; Messi, P. Ready-to-Eat Sandwiches as Source of Pathogens Endowed with Antibiotic Resistance and Other Virulence Factors. Appl. Sci. 2021, 11, 7177. https://doi.org/ 10.3390/app11167177

Academic Editor: Andrea Salvo

Received: 14 July 2021

Accepted: 30 July 2021

Published: 4 August 2021

Publisher's Note: MDPI stays neutral with regard to jurisdictional claims in published maps and institutional affiliations.

Copyright: (c) 2021 by the authors. Licensee MDPI, Basel, Switzerland. This article is an open access article distributed under the terms and conditions of the Creative Commons Attribution (CC BY) license (https:// creativecommons.org/licenses/by/ $4.0 /)$.

\begin{abstract}
The aim of this study was to evaluate and characterize the bacterial load present in twentyfour Ready-To-Eat (RTE) sandwiches, purchased at refrigerated vending machines and supermarkets in the province of Modena (Italy). We isolated 54 bacterial strains, including pathogens of interest in food safety, such as Listeria, Staphylococcus, Enterococcus, Yersinia, Aeromonas and Acinetobacter spp. Phenotypic tests have been performed on these pathogens to detect the presence of virulence factors, such as gelatinase production and hemolytic capability. To test their antibiotic resistance features, the minimum inhibitory concentration (MIC) against eight commonly used antibiotics (Amikacin, Ciprofloxacin, Ampicillin, Oxacillin, Imipenem, Tetracycline, Erythromycin and Vancomycin) was also evaluated. The results showed that among the 54 isolates, fifty percent $(50 \%)$ belonged to harmless microorganisms (Leuconostoc and Lactococcus), whereas the remaining fifty percent (50\%) included pathogenic bacteria (Listeria ivanovii, Listeria monocytogenes, Staphylococcus aureus, Yersinia, and Citrobacter spp.), species responsible for pathologies often difficult to treat due to the presence of antibiotic resistance features. This study demonstrates the importance of thorough controls, both during the production and marketing of RTE food like sandwiches, to avoid reaching the infectious load and the onset of pathologies, particularly dangerous for old and immunocompromised patients.
\end{abstract}

Keywords: sandwiches; pathogens; Listeria; antibiotic resistance; virulence factors

\section{Introduction}

Ready-to-eat food (RTE) is a type of product that must not be cooked or reheated before serving. This includes salads, vegetables, fruits, cooked meats, smoked fish, desserts, sandwiches, cheese and food that are previously cooked in order to be later served cold. The trend towards consumption of minimally processed, ready-to-eat, refrigerated and frozen food products poses new problems to the identification and management of bacterial risks for consumers, mainly due to the inability to maintain a temperature-controlled environment. Even if properly stored, RTE foods can contain high risk ingredients that allow pathogens to grow and multiply. Recent modifications in food production and processing practices and the ever-changing eating habits of the consumers, who appreciate the readiness of RTE foods, have affected the incidence of pathogens that can multiply in such foods. This typology of foods presents more safety and quality complications, because of their susceptibility to bacterial contamination, for the absence of the adequate preservatives and storage temperature during the food chain. These products are usually characterized by a long shelf life at refrigerated temperature and they can be contaminated with spoilage bacteria and foodborne pathogens during all stages of the production process. Like many types of RTE food, sandwiches are tasty and easy to eat, especially for workers who are always in a hurry and eating meals away from home. Sandwiches are a popular RTE food typology that can contain some high-risk ingredients, such as raw vegetables, eggs and salad dressings, and whose preparation usually involves manual handling, which increases the number of potential contamination sources. Many pathogenic bacteria like Listeria, 
Staphylococcus, Shigella, Yersinia spp., ubiquitous bacteria found in many environments like soil or water, can come into contact with these raw or fresh ingredients [1]. Many human pathogens can also be transmitted through bare-hand handlings, like S. aureus, which can be found on human skin and hair, or other pathogens colonizing the intestinal tract. The multi-ingredients used for the production and the sandwich fillings like cheese, chicken, eggs, ham, salad, sauce, and various types of fresh produce contribute to the microbial contamination and have been associated with foodborne illness outbreaks, the last reported in the UK in 2019, where hospitalized patients died after the consumption of sandwiches contaminated by Listeria monocytogenes [2]. The RTE foods preservation techniques are based on low temperatures, which do not prevent some psychrotrophic bacteria from multiplying at refrigeration temperatures, such as L. monocytogenes, a ubiquitous Gram-positive genus that can be isolated from a wide range of food products [3]. This psychrotrophic pathogen may be already present in raw materials, but the risks associated with the consumption of RTE foods [4] could also be due to their presence in processing plant equipment and cross-contamination during the food storage at refrigeration temperature [5]. L. monocytogenes is the most important specie responsible for food-borne outbreaks and severe illness, listeriosis, mainly in elderly consumers, immunocompromised individuals and pregnant women [6], even if other species like L. ivanovii and L. seeligeri have been found in sporadic cases. L. ivanovii has been isolated, although rarely, from infected humans, indicating a pathogenic potential for humans [7]. Although, L. seeligeri carries a virulence gene cluster that is not expressed, it has been associated with rare cases of infections in humans [8,9].

The objective of the present investigation was to examine the microbiological quality of 24 ready-to-eat sandwiches, to evaluate the risk for consumers due to the presence of pathogenic strains, and the presence in the isolates of antibiotic resistance and other virulence factors.

\section{Materials and Methods}

\subsection{Sampling}

Twenty-four sandwiches in modified atmosphere packaging have been purchased on different days from automatic distributors and in supermarkets in the province of Modena, processed within $4 \mathrm{~h}$ of the collection and stored at $4{ }^{\circ} \mathrm{C}$ for the duration of the experiment. The sandwiches contained different ingredient combinations: Tuna and tomato, ham and cheese, tomato and mozzarella cheese, tuna and eggs, turkey and vegetables, shrimp and pink sauce, cooked ham, raw ham, smoked cheese and tomatoes, cooked ham and mushrooms, tuna and onions, cooked ham and artichokes, raw ham and eggplants. The ingredients and the expiry date were recorded, to ensure that the samples were within their shelf-life period at the end of the study.

\subsection{Microbiological Analysis}

Sandwiches samples (25 g) were homogenized using a Stomacher (Lab Blender, Seward, London, UK) for $1 \mathrm{~min}$ in sterile plastic bags, with $225 \mathrm{~mL}$ buffered peptone water added (Oxoid, Milan, Italy). The homogenate samples and the appropriate dilutions were spread on selective and non-selective plates and incubated at $37^{\circ} \mathrm{C}$ for $24-48 \mathrm{~h}$. Tryptic Soy Agar (TSA) was used as a non-selective medium for the total bacterial count, while as selective plates the following media were used: MacConkey Agar (MK) for the isolation of Enterobacteriaceae, Listeria Palcam Agar Base (PAL), for the isolation of species belonging to the genus Listeria, Mannitol Salt Agar (MSA), for the isolation of Staphylococcus spp., Kanamycin Aesculin Azide Agar Base (KA) for Enterococcus spp. (all media from Oxoid, Milan, Italy). After incubation, colonies grown on selective plates were individually cultured to proceed with the identification and biological characterization. All bacterial counts were recorded as $\mathrm{CFU} / \mathrm{g}$. 


\subsection{Identification of Isolates}

The identification of the isolates was obtained using the EnteroPluri-Test (Liofilchem, Italy) to identify microorganisms belonging to the Enterobacteriaceae family and the API ${ }^{\circledR}$ strips (Biomerieux, Marcy l'Etoile, France) for the other genera. Subsequently, the bacterial identification was definitively confirmed by matrix-assisted laser desorption ionization (MALDI) time-of-flight mass spectrometry (TOF/MS). All the strains were stored in phosphate-buffered saline (PBS; $8 \mathrm{~g} \mathrm{NaCl}, 0.2 \mathrm{~g} \mathrm{KCl}, 2.9 \mathrm{~g} \mathrm{Na}_{2} \mathrm{HPO}_{4} \cdot 12 \mathrm{H}_{2} \mathrm{O}, 0.2 \mathrm{~g} \mathrm{KH}_{2} \mathrm{PO}_{4}$ with $1 \mathrm{~L}$ of distilled water) supplemented with $30 \%$ (vol/vol) glycerine at $-80{ }^{\circ} \mathrm{C}$.

\subsection{Evaluation of Virulence Factors: Hemolysin and Gelatinase Production}

Hemolysin and gelatinase production were evaluated in all 54 isolates by spotting the plates added with the specific media with $10 \mu \mathrm{L}$ of suspension, cultured in Tryptic Soy Broth (Oxoid, SpA, Milan, Italy) at $30^{\circ} \mathrm{C}$ for $48 \mathrm{~h}$. For the hemolysin production, all the strains were cultured on blood agar plates containing $5 \%$ of defibrinated horse blood (bioMérieux, Florence, Italy). After incubation at $37^{\circ} \mathrm{C}$ for $24 \mathrm{~h}$, the haemolytic activity was determined by observing a clear zone of haemolysis ( $\beta$-haemolysis), a partial and greening haemolysis zone ( $\alpha$-haemolysis) or no activity ( $\gamma$-haemolysis) around the spots. Gelatinase production was assessed by inoculation of the strains in a Nutrient Broth containing $10 \%$ gelatin. Positive gelatinase was recorded as degradation of the gelatin to liquid. Given that some microorganisms produce low amounts of gelatinase, all negative results were further incubated for up to 15 days to observe any delayed positive reactions.

\subsection{Determination of the Minimum Inhibitory Concentration (MIC)}

The MICs of 30 out of 54 isolated and identified strains have only been evaluated, chosen on the basis of their ability to cause food poisoning. Following the guidelines of the EUCAST (European Committee on Antimicrobial Susceptibility Testing), the MICs were obtained for eight antibiotics: Amikacin, Ciprofloxacin, Ampicillin, Oxacillin, Imipenem, Tetracycline, Erythromycin and Vancomycin (Table 1). The evaluation was carried out using the agar dilution method by adding double dilutions of antibiotics to the MuellerHinton agar medium (Oxoid, SpA, Milan, Italy). The results were then compared with the breakpoints from EUCAST 2021 [10].

Table 1. Mechanism of action of antimicrobial agents used for MICs determination.

\begin{tabular}{|c|c|c|c|}
\hline Antimicrobial Agents & Group & Mechanism of Action & References \\
\hline Amikacin & Aminoglycoside & $\begin{array}{l}\text { Inhibits bacterial protein synthesis and } \\
\text { also affects the barrier function of } \\
\text { bacterial cell membranes. }\end{array}$ & {$[11,12]$} \\
\hline Ciprofloxacin & Quinolone & $\begin{array}{l}\text { Inhibit bacterial DNA gyrase and } \\
\text { interfere with bacterial } \\
\text { DNA replication. }\end{array}$ & {$[13,14]$} \\
\hline Ampicillin & Penicillin (aminopenicillin) & $\begin{array}{l}\text { Inhibition of bacterial cell wall } \\
\text { synthesis by binding one or more of the } \\
\text { penicillin binding proteins (PBPs). }\end{array}$ & {$[15,16]$} \\
\hline Oxacillin & $\beta$-Lactam & $\begin{array}{l}\text { Inhibits the synthesis of bacterial } \\
\text { cell walls. }\end{array}$ & {$[17,18]$} \\
\hline Imipenem & $\beta$-Lactam & $\begin{array}{l}\text { Inhibits the synthesis of bacterial } \\
\text { cell walls. }\end{array}$ & {$[17,18]$} \\
\hline
\end{tabular}


Table 1. Cont.

\begin{tabular}{|c|c|c|c|}
\hline Antimicrobial Agents & Group & Mechanism of Action & References \\
\hline Tetracycline & Tetracycline & $\begin{array}{l}\text { It specifically binds to the bacterial } \\
\text { ribosomal } 30 S \text { subunit at the A position, } \\
\text { prevents the connection of } \\
\text { aminoacyl-tRNA at this position, and } \\
\text { inhibits protein synthesis. }\end{array}$ & {$[19,20]$} \\
\hline Erythromycin & Macrolide & $\begin{array}{l}\text { Combines with bacterial ribosomal } 50 S \\
\text { subunit to inhibit peptide } \\
\text { acyltransferase and bacterial } \\
\text { protein synthesis. }\end{array}$ & {$[21,22]$} \\
\hline Vancomycin & Glycopeptide & $\begin{array}{l}\text { Inhibits the synthesis of bacterial } \\
\text { cell walls. }\end{array}$ & {$[23,24]$} \\
\hline
\end{tabular}

\section{Results}

\subsection{Quantification and Identification of the Isolates}

A total bacterial count from $10^{4} \mathrm{CFU} / \mathrm{g}$ to $10^{6} \mathrm{CFU} / \mathrm{g}$ was found on the non-selective TSA medium for the most processed sandwiches produced with the greatest amount of ingredients and the most manipulated ones (meats, sauces and vegetables of different types). Fifty-four strains were isolated from both samples and ingredients on selective media MSA, KA, PAL, MK with bacterial load ranging from $10^{2}$ to $10^{5} \mathrm{CFU} / \mathrm{g}, 10^{2}$ to $10^{4} \mathrm{CFU} / \mathrm{g}, 10^{3}$ to $10^{4} \mathrm{CFU} / \mathrm{g}$, and $10^{2}$ to $10^{3} \mathrm{CFU} / \mathrm{g}$, respectively. Of the 54 strains examined, twenty (37.04\%) belonged to the genera Staphylococcus, eight (14.81\%) to Leuconostoc, five to $(9.26 \%)$ Listeria, five $(9.26 \%)$ to Aerococcus, four $(7.41 \%)$ to Lactococcus, four $(7.41 \%)$ to Enterococcus, four (7.41\%) to Acinetobacter, two (3.70\%) to Aeromonas, one $(1.85 \%)$ to Citrobacter, one $(1.85 \%)$ to Yersinia (the last two referred together in the figure as Enterobacteriaceae) (Figure 1).

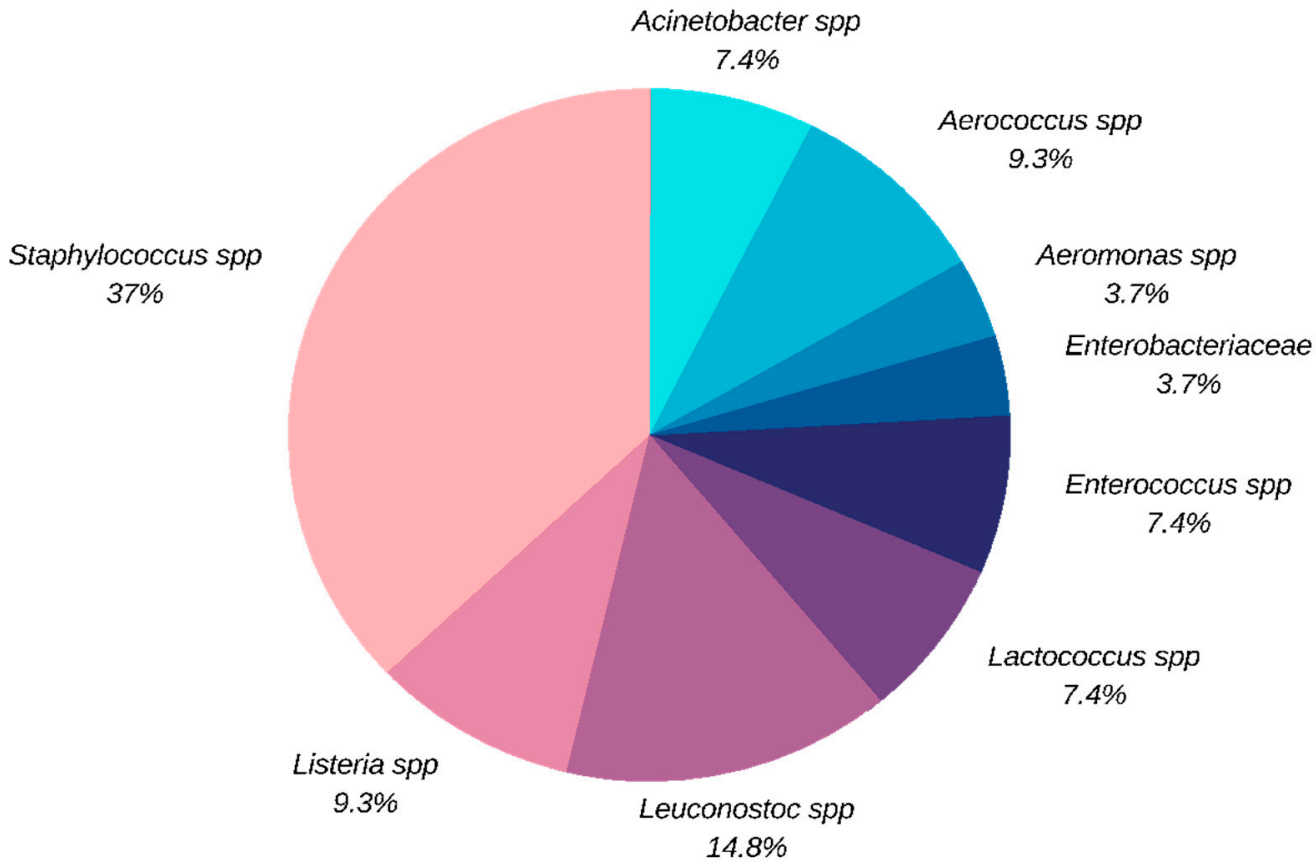

Figure 1. Bacterial species detected in the selective plates.

Staphylococcus is the most represented genus, with bacterial load ranging from $10^{2}$ to $10^{5} \mathrm{CFU} / \mathrm{g}$. Notably, S. aureus was found on 14 samples and in 8 of these it was the only contaminant. Regarding to the other Gram-positive strains, Enterococcus was the second isolated genus, found in three samples, and represented by E. faecium (2 strains), E. avium 
(1 strain) and E. durans (1 strain), followed by five Aerococcus viridans isolates. Leuconostoc and Lactococcus were also found, both genera used as commercial starters in the bakery sectors. Among the Gram-negative strains, in three samples bacterial loads between $10^{3}$ and $10^{4} \mathrm{CFU} / \mathrm{g}$ were found on MacConkey Agar (MK). Aeromonas hydrophila was isolated from one sample, and it was also present in another one together with Citrobacter spp., whereas in a third sample the simultaneous presence of Yersinia enterocolitica and Acinetobacter lwoffii was observed. Last, four Listeria ivanovii subsp. londoniensis and one Listeria welshimeri were isolated from three sandwiches, with bacterial loads around $10^{2} \mathrm{CFU} / \mathrm{g}$ for all isolates.

\subsection{Determination of the Minimum Inhibitory Concentration}

As reported in Table 1, all E. faecium strains were resistant to Vancomycin $(8 \mu \mathrm{g} / \mathrm{mL})$, while only one of these presented a resistance to Ampicillin and Erythromycin $(16 \mu \mathrm{g} / \mathrm{mL})$. E. avium and E. durans, following EUCAST guidelines, were tested only against Ampicillin and Vancomycin, to which they were sensitive (Table 2).

Table 2. MIC values for Enterococci strains and their Break Point values.

\begin{tabular}{lccccc}
\hline \multicolumn{1}{c}{ Strains } & Ciprofloxacin & Tetracycline & Ampicillin & Erythromycin & Vancomycin \\
\hline E. faecium EC1 & $4 \mu \mathrm{g} / \mathrm{mL}$ & $1 \mu \mathrm{g} / \mathrm{mL}$ & $16 \mu \mathrm{g} / \mathrm{mL}$ & $16 \mu \mathrm{g} / \mathrm{mL}$ & $8 \mu \mathrm{g} / \mathrm{mL}$ \\
E. faecium EC2 & $4 \mu \mathrm{g} / \mathrm{mL}$ & $1 \mu \mathrm{g} / \mathrm{mL}$ & $4 \mu \mathrm{mL}$ & $4 \mu \mathrm{m} / \mathrm{mL}$ & $8 \mu \mathrm{g} / \mathrm{mL}$ \\
E. avium EC16 & $/$ & $/$ & $1 \mu \mathrm{g} / \mathrm{mL}$ & $/$ & $2 \mu \mathrm{mL}$ \\
E. durans EC17 & $/$ & $/$ & $2 \mu \mathrm{mL} / \mathrm{mL}$ & $/$ & $2 \mu \mathrm{g} / \mathrm{mL}$ \\
BREAKPOINT & $\geq 8 \mu \mathrm{g} / \mathrm{mL}$ & $\geq 4 \mu \mathrm{g} / \mathrm{mL}$ & $\geq 8 \mu \mathrm{g} / \mathrm{mL}$ & $\geq 4 \mu \mathrm{g} / \mathrm{mL}$ & $\geq 4 \mu \mathrm{g} / \mathrm{mL}$ \\
\hline
\end{tabular}

All 13 S. aureus strains were sensitive to Amikacina. Only S. aureus S29 and S41 were sensitive to Ciprofloxacin, while the other 11 strains showed a "Susceptible, increased exposure" (MIC value at the breakpoint). Only one isolate (S. aureus S26) is endowed with a multi-resistance to Erythromycin $(2 \mu \mathrm{g} / \mathrm{mL})$ and Oxacillin $(4 \mu \mathrm{g} / \mathrm{mL})$. It is important to note that most isolates presented a "Susceptible, increased exposure" profile (Table 3).

Table 3. MIC values for Staphylococcus aureus strains and their Break Point values.

\begin{tabular}{lccccc}
\hline \multicolumn{1}{c}{ Strains } & Amikacin & Ciprofloxacin & Erythromicin & Vancomiycin & Oxacillin \\
\hline S. aureus S26 & $1 \mu \mathrm{g} / \mathrm{mL}$ & $1 \mu \mathrm{g} / \mathrm{mL}$ & $2 \mu \mathrm{g} / \mathrm{mL}$ & $1 \mu \mathrm{g} / \mathrm{mL}$ & $4 \mu \mathrm{g} / \mathrm{mL}$ \\
S. aureus S28 & $1 \mu \mathrm{g} / \mathrm{mL}$ & $1 \mu \mathrm{g} / \mathrm{mL}$ & $1 \mu \mathrm{g} / \mathrm{mL}$ & $1 \mu \mathrm{g} / \mathrm{mL}$ & $2 \mu \mathrm{g} / \mathrm{mL}$ \\
S. aureus S29 & $1 \mu \mathrm{g} / \mathrm{mL}$ & $0.25 \mu \mathrm{g} / \mathrm{mL}$ & $0.5 \mu \mathrm{g} / \mathrm{mL}$ & $0.5 \mu \mathrm{g} / \mathrm{mL}$ & $2 \mu \mathrm{g} / \mathrm{mL}$ \\
S. aureus S31 & $1 \mu \mathrm{g} / \mathrm{mL}$ & $1 \mu \mathrm{g} / \mathrm{mL}$ & $2 \mu \mathrm{g} / \mathrm{mL}$ & $2 \mu \mathrm{g} / \mathrm{mL}$ & $2 \mu \mathrm{g} / \mathrm{mL}$ \\
S. aureus S32 & $1 \mu \mathrm{g} / \mathrm{mL}$ & $1 \mu \mathrm{g} / \mathrm{mL}$ & $0.5 \mu \mathrm{g} / \mathrm{mL}$ & $2 \mu \mathrm{g} / \mathrm{mL}$ & $4 \mu \mathrm{g} / \mathrm{mL}$ \\
S. aureus S33 & $1 \mu \mathrm{g} / \mathrm{mL}$ & $1 \mu \mathrm{g} / \mathrm{mL}$ & $2 \mu \mathrm{g} / \mathrm{mL}$ & $2 \mu \mathrm{g} / \mathrm{mL}$ & $2 \mu \mathrm{g} / \mathrm{mL}$ \\
S. aureus S34 & $1 \mu \mathrm{g} / \mathrm{mL}$ & $1 \mu \mathrm{g} / \mathrm{mL}$ & $1 \mu \mathrm{g} / \mathrm{mL}$ & $2 \mu \mathrm{g} / \mathrm{mL}$ & $2 \mu \mathrm{g} / \mathrm{mL}$ \\
S. aureus S35 & $1 \mu \mathrm{g} / \mathrm{mL}$ & $1 \mu \mathrm{g} / \mathrm{mL}$ & $0.5 \mu \mathrm{g} / \mathrm{mL}$ & $2 \mu \mathrm{g} / \mathrm{mL}$ & $1 \mu \mathrm{g} / \mathrm{mL}$ \\
S. aureus S36 & $1 \mu \mathrm{g} / \mathrm{mL}$ & $1 \mu \mathrm{g} / \mathrm{mL}$ & $0.5 \mu \mathrm{g} / \mathrm{mL}$ & $2 \mu \mathrm{g} / \mathrm{mL}$ & $2 \mu \mathrm{g} / \mathrm{mL}$ \\
S. aureus S37 & $1 \mu \mathrm{g} / \mathrm{mL}$ & $1 \mu \mathrm{g} / \mathrm{mL}$ & $0.5 \mu \mathrm{g} / \mathrm{mL}$ & $2 \mu \mathrm{g} / \mathrm{mL}$ & $1 \mu \mathrm{g} / \mathrm{mL}$ \\
S. aureus S41 & $1 \mu \mathrm{g} / \mathrm{mL}$ & $0.25 \mu \mathrm{g} / \mathrm{mL}$ & $0.5 \mu \mathrm{g} / \mathrm{mL}$ & $2 \mu \mathrm{g} / \mathrm{mL}$ & $1 \mu \mathrm{g} / \mathrm{mL}$ \\
S. aureus S42 & $1 \mu \mathrm{g} / \mathrm{mL}$ & $1 \mu \mathrm{g} / \mathrm{mL}$ & $0.5 \mu \mathrm{g} / \mathrm{mL}$ & $1 \mu \mathrm{g} / \mathrm{mL}$ & $1 \mu \mathrm{g} / \mathrm{mL}$ \\
S. aureus S43 & $1 \mu \mathrm{g} / \mathrm{mL}$ & $1 \mu \mathrm{g} / \mathrm{mL}$ & $0.5 \mu \mathrm{g} / \mathrm{mL}$ & $2 \mu \mathrm{g} / \mathrm{mL}$ & $2 \mu \mathrm{g} / \mathrm{mL}$ \\
BREAKPOINT & $\geq 16 \mu \mathrm{g} / \mathrm{mL}$ & $\geq 1 \mu \mathrm{g} / \mathrm{mL}$ & $\geq 1 \mu \mathrm{g} / \mathrm{mL}$ & $\geq 2 \mu \mathrm{g} / \mathrm{mL}$ & $\geq 2 \mu \mathrm{g} / \mathrm{mL}$ \\
\hline
\end{tabular}

In relation to the psychrotrophic bacteria, the five Listeria isolates (Table 4) were resistant to Erythromycin. In relation to Tetracycline, all L. ivanovii londoniensis showed a "Susceptible, increased exposure" profile, while L. welshimeri was resistant to the compound, with MIC value of $4 \mu \mathrm{g} / \mathrm{mL}$. Four strains (3 strains of L. ivanovii spp. londoniensis with a value of $2 \mu \mathrm{g} / \mathrm{mL}$ and L. welshimeri with value of $4 \mu \mathrm{g} / \mathrm{mL}$ ) was resistant to Ampicillin. The two strains of $A$. hydrophila were evaluated only against Imipenem to which they were resistant, with values of $2 \mu \mathrm{g} / \mathrm{mL}$. Whereas Y. enterocolitica showed a "Susceptible, 
increased exposure" profile for Ciprofloxacin and Tetracycline, with value of $0.25 \mu \mathrm{g} / \mathrm{mL}$, and $4 \mu \mathrm{g} / \mathrm{mL}$, respectively (Table 5).

Table 4. MIC values for Listeria strains and Break Point values.

\begin{tabular}{lccc}
\hline \multicolumn{1}{c}{ Strains } & Tetracycline & Ampicillin & Erythromycin \\
\hline L. ivanovii spp. londoniensis 46L & $1 \mu \mathrm{g} / \mathrm{mL}$ & $2 \mu \mathrm{g} / \mathrm{mL}$ & $2 \mu \mathrm{g} / \mathrm{mL}$ \\
L. ivanovii spp. londoniensis 47L & $1 \mu \mathrm{g} / \mathrm{mL}$ & $2 \mu \mathrm{g} / \mathrm{mL}$ & $2 \mu \mathrm{g} / \mathrm{mL}$ \\
L. ivanovii spp. londoniensis 48L & $1 \mu \mathrm{g} / \mathrm{mL}$ & $2 \mu \mathrm{g} / \mathrm{mL}$ & $2 \mu \mathrm{g} / \mathrm{mL}$ \\
L. ivanovii spp. londoniensis 49L & $1 \mu \mathrm{g} / \mathrm{mL}$ & $0.5 \mu \mathrm{g} / \mathrm{mL}$ & $2 \mu \mathrm{g} / \mathrm{mL}$ \\
L. welshimeri 50L & $4 \mu \mathrm{g} / \mathrm{mL}$ & $4 \mu \mathrm{g} / \mathrm{mL}$ & $2 \mu \mathrm{g} / \mathrm{mL}$ \\
BREAKPOINT & $\geq 1 \mu \mathrm{g} / \mathrm{mL}$ & $\geq 1 \mu \mathrm{g} / \mathrm{mL}$ & $\geq 1 \mu \mathrm{g} / \mathrm{mL}$ \\
\hline
\end{tabular}

Table 5. MIC values for A. hydrophila and Y. enterocolitica strains and Break Point values.

\begin{tabular}{lccc}
\hline \multicolumn{1}{c}{ Strain } & Imipenem & Ciprofloxacin & Tetracyclin \\
\hline A. hydrophila 52EB & $2 \mu \mathrm{g} / \mathrm{mL}$ & & \\
A. hydrophila 59EB & $2 \mu \mathrm{g} / \mathrm{mL}$ & & \\
BREAKPOINT & $\geq 1 \mu \mathrm{g} / \mathrm{mL}$ & & \\
Y. enterocolitica 58EB & & $0.25 \mu \mathrm{g} / \mathrm{mL}$ & $4 \mu \mathrm{g} / \mathrm{mL}$ \\
BREAKPOINT & & $\geq 0.25 \mu \mathrm{g} / \mathrm{mL}$ & $\geq 4 \mu \mathrm{g} / \mathrm{mL}$ \\
\hline
\end{tabular}

Lastly, all the Acinetobacter species are sensitive to both the antibiotic Amikacin and Ciprofloxacin, and the only isolate belonging to the genus Citrobacter tested against Amikacin showed a resistance profile with a value of $16 \mu \mathrm{g} / \mathrm{mL}$ (Table 6).

Table 6. MIC values for Acinetobacter and Citrobacter strains and Break Point values.

\begin{tabular}{ccc}
\hline Strains & Amikacin & Ciprofloxacin \\
\hline A. Iwofii 54EB & $2 \mu \mathrm{g} / \mathrm{mL}$ & $0.25 \mu \mathrm{g} / \mathrm{mL}$ \\
A. calcoaceticus 55EB & $2 \mu \mathrm{g} / \mathrm{mL}$ & $0.25 \mu \mathrm{g} / \mathrm{mL}$ \\
A. Iwofii 56EB & $2 \mu \mathrm{g} / \mathrm{mL}$ & $0.25 \mu \mathrm{g} / \mathrm{mL}$ \\
A. Iwofii 57EB & $2 \mu \mathrm{g} / \mathrm{mL}$ & $0.25 \mu \mathrm{g} / \mathrm{mL}$ \\
BREAKPOINT & $\geq 8 \mu \mathrm{g} / \mathrm{mL}$ & $\geq 1 \mu \mathrm{g} / \mathrm{mL}$ \\
\hline
\end{tabular}

\subsection{Phenotypical Virulence Factors}

The results of the virulence tests (Figure 2a,b) showed that hemolytic and gelatinase activities were present in $40,74 \%$ and $18,52 \%$ of the isolates, respectively. Five strains $(9.26 \%)$ showed $\alpha$-hemolytic activity, seventeen strains (31.48\%) $\beta$-hemolytic activity and in thirty-two strains (59.26\%) this feature was not present. All S. aureus and 4 out 5 Listeria spp. (L. ivanovii) are endowed with $\beta$-hemolytic virulence factor (Figure 3). All Listeria and 3 out 4 Acinetobacter spp. could hydrolyze the gelatin, keeping the culture medium liquid even at temperatures below the solidification point. Two strains (Staphylococcus aureus $28 \mathrm{~S}$ and Staphylococcus aureus 37S) showed a partial gelatinase capacity, corresponding to an incomplete solidification of the media at low temperatures (Figure 4). 

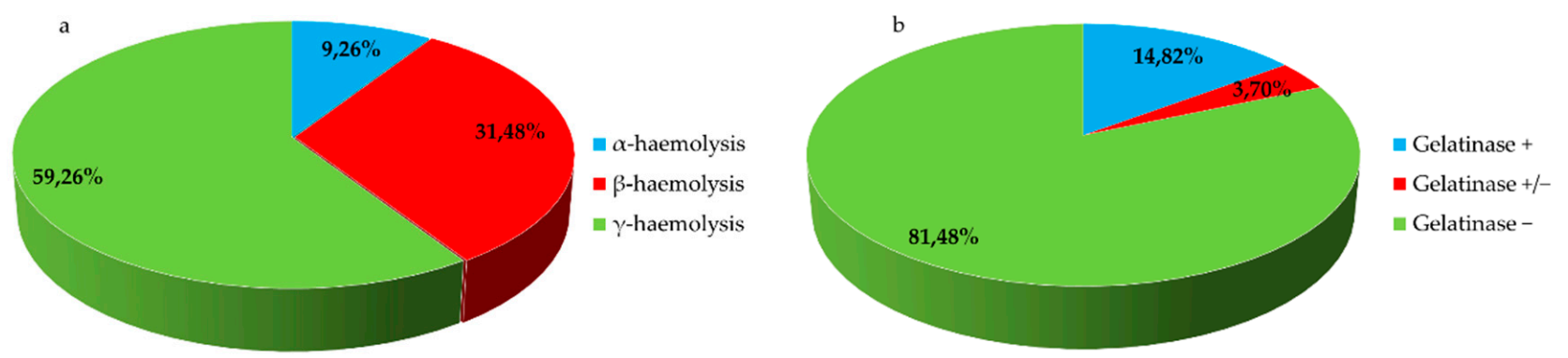

Figure 2. $(\mathbf{a}, \mathbf{b})$ Haemolysis and gelatinase test results for all tested strains.

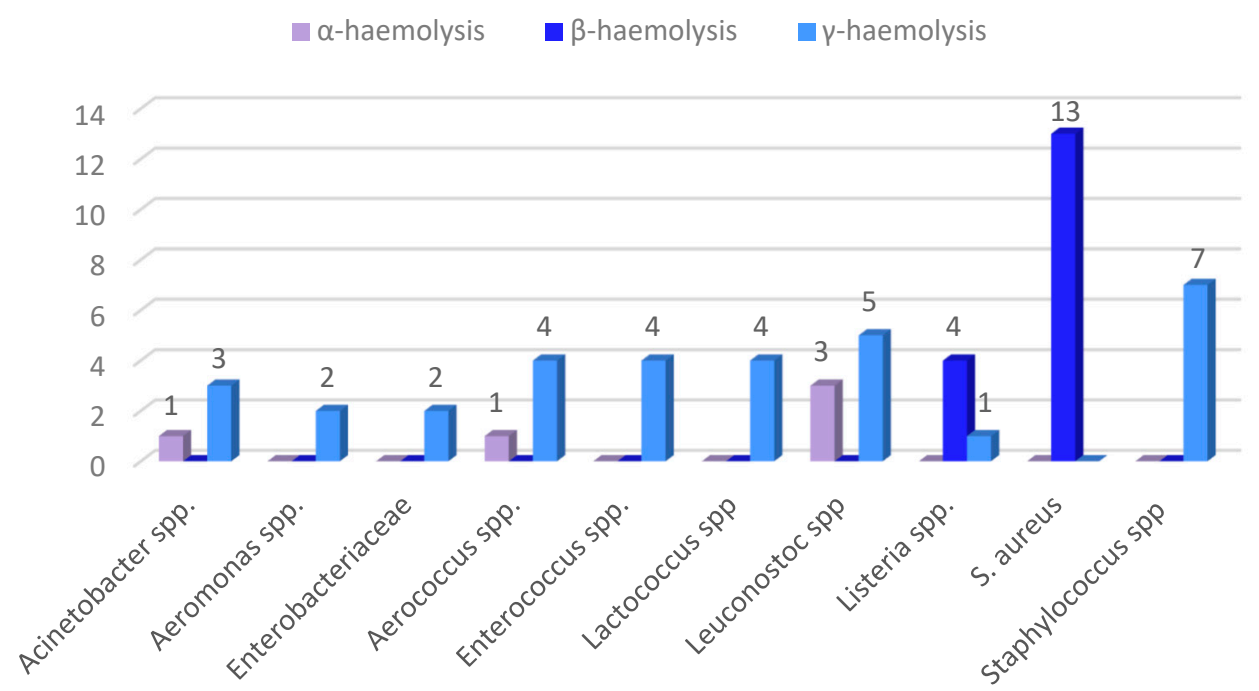

Figure 3. Haemolysis test results.

- Positive Partial Negative
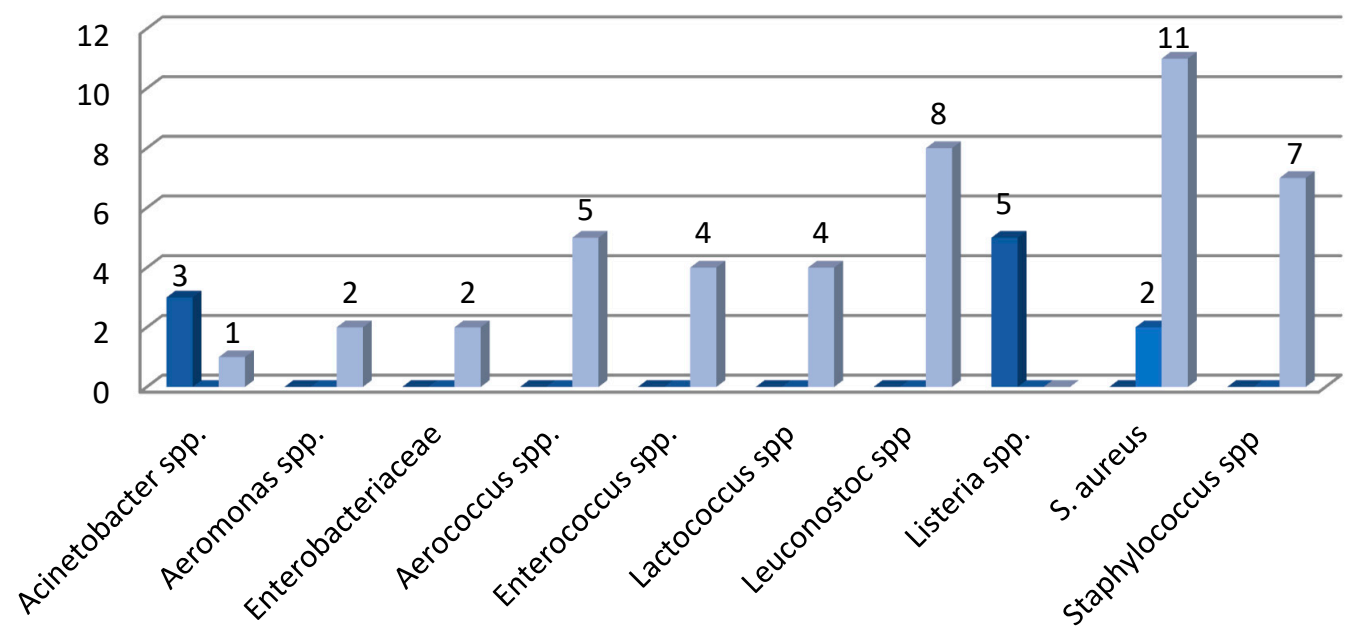

Figure 4. Gelatinase test results.

\section{Discussion}

Microbiological contamination is distributed throughout the food processing chain, from its production to consumption. The risks are greater in foods, which do not require further heating before consumption, such as ready to eat (RTE) products. Moreover, low hygiene practices during handling, cross- contamination and poor refrigerated temperature control may be responsible for exposure to pathogens bacteria through the food chain. The 
European Food Safety Authority believes that up to $90 \%$ of listeriosis cases occurring from 2008 to 2015 are due to the consumption of RTE foods, such as smoked fish, preserved meat and cheeses, and also vegetables, such as ready to eat salads. A third of the cases was due to the proliferation of Listeria spp., Staphylococcus spp., Shigella, Y. enterocolitica and other pathogenic bacteria found in foods incorrectly stored in the refrigerated vending machine [25-27].

The present study showed that among the 54 isolates, 25 strains (46.3\%) belonged to harmless microorganisms, including Leuconostoc and Lactococcus, lactobacilli used as starters in fermentation processes of cheese or bread, whereas the remaining 27 strains (53.7\%) belonged to pathogenic bacteria (13 S. aureus, 5 Listeria spp., 4 Enterococcus spp., 4 Acinetobacter spp., one Y. enterocolitica, one A. hydrophila, and one Citrobacter spp.). The pathogens present in some samples were frequently found with a microbial load exceeding the limits of the EC Regulation 2073/2005 [28], as in the case of the eight samples contaminated with $S$. aureus only. In other studies $S$. aureus was found in RTE products, especially in cold served salads and sandwiches [29,30], tracing its presence in ingredients, such as vegetables and/or fruit and products of animal origin (meat, sausages) [31]. $S$. aureus, by the production of a thermostable toxin, is the species most frequently responsible for food poisoning (the third pathogen for food-borne diseases). S. aureus poisoning is a pathology of a modest clinical entity but has a strong socio-economic impact as it is highly widespread. In the present investigation some samples were contaminated by two or more pathogenic bacteria at the same time. Sample 3, a product characterized by many components and therefore subjected to multiple manipulations, showed the presence not only of S. aureus, but also of L. ivanovii and Citrobacter spp. In sample 6, a shrimp-based product, both Y. enterocolitica and L. ivanovii were isolated. L. ivanovii was recently associated with sporadic human infections, although it is usually linked to animal infections, in particular ruminants, and this microorganism is known as a milk and cheese contaminant [32]. Citrobacter species, belonging to the Enterobacteriaceae family, are considered opportunistic pathogens for humans, but for their wide distribution in the environment and intestinal tracts, they have the capability to be transferred from the farm to fresh produce destined for consumption, thereby constituting a public health risk [33]. Yersiniosis is the third most commonly reported zoonosis in Europe, mainly for the consumption of pig meat and products thereof [25]. In some European countries $Y$. enterocolitica, the dominating species among human diseases is a more significant concern than Salmonella because it can grow at refrigeration temperature [34]. As a psychrotrophic microorganism, a significant health threat is posed by refrigerated products where this pathogen, as well as Listeria and Aeromonas, can proliferate. A. hydrophila is a microorganism found in water, considered the most important infectious reservoir [35], and consequently, it is mainly isolated from seafood and vegetables. It rarely causes food outbreaks, the most recent reported in Sweden and Norway [36]. Acinetobacter is rarely associated with diarrheal disease but A. baumannii, specie found in four sandwiches, possess pathogenetic features, including antibiotic resistance, and could represent a risk for humans, linked to the consumption of contaminated foods (dairy products, raw fruit and vegetables) [37]. Enterococcus spp. have been recognized as emerging human pathogens in recent years, always endowed with antibiotic resistance and other virulence factors $[38,39]$. They seem to also be involved in the production of biogenic amines in some fermented foods [40]. The intoxication, caused by the ingestion of these compounds, can cause the onset of various symptoms, such as headache, vomiting up to the manifestation of severe allergic reactions.

In relation to the virulence traits, this study has highlighted that all the L. ivanovii and three out of four A. baumannii were endowed with hemolytic and gelatinase activity. Lastly, 13 isolates showed a profile of antibiotic resistance. The half presented a multiple resistance profile among the antibiotic-resistant strains, in particular, three out of four Listeria and the only two resistant Enterococcus strains. Most of the MICs evaluated (19 out 30, 63.3\%) showed a "Susceptible, increased exposure" profile (MIC value at the breakpoint); in particular, all S. aureus, L. ivanovii and Y. enterocolitica strains. The isolation of 
antibiotics resistant and of "Susceptible, increased exposure" strains is of concern not only for the consequent therapeutic use difficulties, but also because this characteristic can be transferred by conjugation to different species within the food microbial community [41,42]. Antibiotic resistance is encoded by genes usually located on mobile genetic elements that may transfer to human pathogens in retail food microflora. Conditions with a "Susceptible, increased exposure" could allow the coexistence in the microbial community of both very resistant strains that grow poorly in the absence of antibiotics and less susceptible strains that grow well in the absence of antibiotics [43].

\section{Conclusions}

The variety of pathogens isolated in the present study is a source of health concern, as the consumption of RTE foods, has continuously increased, consistent with the consumers' ever-changing eating habits.

For this type of product, the preservation techniques are based primarily on the use of low temperatures, which do not prevent the growth of some psychrotrophic bacteria, and given this RTE food is eaten without cooking, there is also no control of mesophilic pathogens. Therefore, there is a need to increase the level of attention and awareness, following good hygiene practices throughout the food chain (from farm to fork), notably by producers, to prevent pathogens contamination during preparation, handling and storage. Among the preventive activities able to significantly reduce the health risk is the addition of natural antimicrobial compounds (essential oils, plant extracts, or bacteriocins) to reduce the amounts of preservatives added in RTE products [44,45]. Natural antimicrobials show an antioxidant and antimicrobial activity against a wide range of food pathogens and spoilage bacteria, in order to extend RTE sandwiches shelf-life without altering the sensory properties [46]. The increasing importance attributed to the quality and safety of food has prompted the European Union in 2004 to draw up a series of regulations, which entered into force in Italy in 2006, known as the "Hygiene Package". The EC regulation $852 / 2004$ [47] is responsible for ensuring the hygiene and safety of food products "from farm to table", thus, from the production area (farm) up to consumers (table). It sets both general and specific hygiene requirements to be applied to personnel, means of transport and places where food is processed and sold. It also requires the implementation of the HACCP (Hazard Analysis and Critical Control Points) system, applying the principle of self-control which incentives food business operators to adopt various measures to monitor the healthiness of the finished product. In conclusion, our results show that sandwiches could be a health risk, in particular for susceptible individuals, as they can be a vehicle for the transmission of food-borne pathogens. The quantification and identification of bacterial strains isolated from the various sandwiches show how products with more components, and consequently more manipulated are the most contaminated ones. In particular, the isolation of S. aureus from a lot of samples leads us to believe that food handling is the most likely cause of bacterial contamination, followed by contamination caused by an inaccurate washing of the vegetables present in the food [29], as evidenced by the presence of other species like Listeria, Enterococcus, Enterobacteriaceae and bacteria belonging to the genera Acinetobacter, Aerococcus and Aeromonas. These results underline, once again, the need for better hygienic conditions during food processing, together with the choice of quality raw products. Given the presence of possible hygienic deficiencies in the production chain of some products examined, careful controls are of fundamental importance, both during the food processing and marketing, to avoid the onset of infections difficult to treat, especially in weaker subjects.

Author Contributions: Conceptualization, P.M. and R.I.; methodology R.I.; software, R.I. and C.C.; investigation, S.C. and R.I.; data curation, S.C. and C.C.; writing-original draft preparation, S.C.; writing - review and editing, P.M and R.I. All authors have read and agreed to the published version of the manuscript.

Funding: This research received no external funding. 
Institutional Review Board Statement: Not applicable.

Informed Consent Statement: Not applicable.

Data Availability Statement: Not applicable.

Conflicts of Interest: The authors declare no conflict of interest.

\section{References}

1. Callejón, R.M.; Rodríguez-Naranjo, M.I.; Ubeda, C.; Hornedo-Ortega, R.; Garcia-Parrilla, M.C.; Troncoso, A.M. Reported foodborne outbreaks due to fresh produce in the United States and European Union: Trends and causes. Foodborne Pathog. Dis. 2015, 12, 32-38. [CrossRef]

2. Listeriosis in England and Wales: Summary for 2019. Available online: https://www.gov.uk/government/publications/listeriamonocytogenes-surveillance-reports/listeriosis-in-england-and-wales-summary-for-2019 (accessed on 13 July 2021).

3. Guerra, M.M.; Mclauchlin, J.; Bernardo, F.A. Listeria in ready-to-eat and unprocessed foods produced in Portugal. Food Microbiol. 2001, 18, 423-429. [CrossRef]

4. $\quad$ EFSA BIOHAZ Panel (EFSA Panel on Biological Hazards); Ricci, A.; Allende, A.; Bolton, D.; Chemaly, M.; Davies, R.; Fernandez Escamez,, P.S.; Girones, R.; Herman, L.; Koutsoumanis, K.; et al. Scientific Opinion on the Listeria monocytogenes contamination of ready-to-eat foods and the risk for human health in the EU. EFSA J. 2018, 16, e05134. [CrossRef]

5. Tompkin, R.B. Control of Listeria monocytogenes in the food-processing environment. J Food Prot. 2002, 65, 709-725. [CrossRef]

6. Swaminathan, B.; Gerner-Smidt, P. The epidemiology of human listeriosis. Microbes Infect. 2007, 9, 1236-1243. [CrossRef] [PubMed]

7. Guillet, C.; Join-Lambert, O.; Le Monnier, A.; Leclercq, A.; Mechaï, F.; Mamzer-Bruneel, M.F.; Bielecka, M.K.; Scortti, M.; Disson, O.; Berche, P.; et al. Human listeriosis caused by Listeria ivanovii. Emerg. Infect. Dis. 2010, 16, 136-138. [CrossRef]

8. Hofer, E.; Ribeiro, R.; Feitosa, D.P. Species and serovars of the genus Listeria isolated from different sources in Brazil from 1971 to 1997. Mem. Inst. Oswaldo Cruz. 2000, 95, 615-620. [CrossRef] [PubMed]

9. Snapir, Y.M.; Vaisbein, E.; Nassar, F. Low virulence but potentially fatal outcome-Listeria ivanovii. Eur. J. Intern. Med. 2006, 17, 286-287. [CrossRef] [PubMed]

10. EUCAST 2021. European Committee on Antimicrobial Susceptibility Testing European Committee on Antimicrobial Susceptibility Testing (EUCAST) (2021) Clinical-Breakpoints; Version 11.0; Växjö, Sweden. Wiley: Hoboken, NJ, USA, 2021; Available online: https:/ / eucast.org/clinical_breakpoints (accessed on 13 July 2021).

11. Davis, B.D. Mechanism of bactericidal action of aminoglycosides. Microbiol. Rev. 1987, 51, 341-350. [CrossRef]

12. Krause, K.M.; Serio, A.W.; Kane, T.R.; Connolly, L.E. Aminoglycosides: An overview. Cold Spring Harb. Perspect. Med. 2016, 6, a027029. [CrossRef] [PubMed]

13. Smith, J.T. Wirkmechanismus der Chinolone [Mechanism of action of quinolones]. Infection 1986, 14, S3-S15. [CrossRef]

14. Aldred, K.J.; Kerns, R.J.; Osheroff, N. Mechanism of quinolone action and resistance. Biochemistry 2014, 53, 1565-1574. [CrossRef]

15. Wilkowske, C.J. The penicillins. Mayo Clin. Proc. 1977, 52, 616-624. [PubMed]

16. Peechakara, B.V.; Basit, H.; Gupta, M. Ampicillin. In StatPearls; StatPearls Publishing: Treasure Island, FL, USA, 2021.

17. Frère, J.M. Mechanism of action of beta-lactam antibiotics at the molecular level. Biochem. Pharmacol. 1977, 26, 2203-2210. [CrossRef]

18. Bush, K.; Bradford, P.A. $\beta$-Lactams and $\beta$-Lactamase inhibitors: An overview. Cold Spring Harb. Perspect. Med. 2016, 6, a025247. [CrossRef]

19. Laskin, A.I.; Last, J.A. Tetracyclines. Antibiot. Chemother. 1971, 17, 1-28. [CrossRef] [PubMed]

20. Shutter, M.C.; Akhondi, H. Tetracycline. In StatPearls; StatPearls Publishing: Treasure Island, FL, USA, 2021.

21. Tanaka, S.; Otaka, T.; Kaji, A. Further studies on the mechanism of erythromycin action. Biochim. Biophys. Acta 1973, 331, 128-140. [CrossRef]

22. Vázquez-Laslop, N.; Mankin, A.S. How Macrolide Antibiotics Work. Trends Biochem. Sci. 2018, 43, 668-684. [CrossRef]

23. Zeng, D.; Debabov, D.; Hartsell, T.L.; Cano, R.J.; Adams, S.; Schuyler, J.A.; McMillan, R.; Pace, J.L. Approved glycopeptide antibacterial drugs: Mechanism of action and resistance. Cold Spring Harb. Perspect. Med. 2016, 6, a026989. [CrossRef]

24. Patel, S.; Preuss, C.V.; Bernice, F. Vancomycin. In StatPearls; StatPearls Publishing: Treasure Island, FL, USA, 2021.

25. European Food Safety Authority, European Centre for Disease Prevention and Control. The European Union Summary report on trends and sources of zoonoses, zoonotic agents and foodborne outbreaks in 2013. EFSA J. 2015, 13, 3991.

26. El-Shenawy, M.; El-Shenawy, M.; Mañes, J.; Soriano, J.M. Listeria spp. in street-vended Ready-to-Eat foods. Interdiscip. Perspect. Infect. Dis. 2011, 2011, 968031. [CrossRef] [PubMed]

27. Cossu, F.; Spanu, C.; Deidda, S.; Mura, E.; Casti, D.; Pala, C.; Lamon, S.; Spanu, V.; Ibba, M.; Marrocu, E.; et al. Listeria Spp. and Listeria monocytogenes contamination in Ready-To-Eat sandwiches collected from vending machines. Ital. J. Food Saf. 2016, 5, 5500. [CrossRef]

28. Commission Regulation (EC) No 2073/2005 of 15 November 2005 on microbiological criteria for foodstuffs. Off. J. 2005, 338, 1-26. Available online: https:/ / eur-lex.europa.eu/legal-content/EN/ALL/?uri=CELEX\%3A32005R2073 (accessed on 13 July 2021).

29. Jang, H.G.; Kim, N.H.; Choi, Y.M.; Rhee, M.S. Microbiological quality and risk factors related to sandwiches served in bakeries, cafe's and sandwich bars in South Korea. J. Food Protect. 2013, 76, 231-238. [CrossRef] [PubMed] 
30. Soares, K.; Moura, A.T.; García-Díez, J.; Oliveira, I.; Esteves, A.; Saraiva, C. Evaluation of hygienic quality of food served in Universities canteens of northem Portugal. Indian J. Microbiol. 2020, 60, 107-114. [CrossRef] [PubMed]

31. Fijałkowski, K.; Peitler, D.; Karakulska, J. Staphylococci isolated from ready-to-eat meat-Identification, antibiotic resistance and toxin gene profile. Int. J. Food Microbiol. 2016, 238, 113-120. [CrossRef] [PubMed]

32. Alvarez-Ordóñez, A.; Leong, D.; Morgan, C.A.; Hill, C.; Gahan, C.G.; Jordan, K. Occurrence, persistence, and virulence potential of Listeria ivanovii in foods and food processing environments in the Republic of Ireland. Biomed. Res. Int. 2015, $2015,350526$. [CrossRef] [PubMed]

33. Iwu, C.D.; Okoh, A.I. Preharvest transmission routes of fresh produce associated bacterial pathogens with outbreak potentials: A Review. Int. J. Environ. Res. Public Health 2019, 16, 4407. [CrossRef] [PubMed]

34. Le Guern, A.S.; Martin, L.; Savin, C.; Carniel, E. Yersiniosis in France: Overview and potential sources of infection. Int. J. Infect. Dis. 2016, 46, 1-7. [CrossRef]

35. Igbinosa, I.H.; Igumbor, E.U.; Aghdasi, F.; Tom, M.; Okoh, A.I. Emerging Aeromonas species infections and their significance in public health. Sci. World J. 2012, 2012, 625023. [CrossRef]

36. Hoel, S.; Vadstein, O.; Jakobsen, A.N. The significance of mesophilic Aeromonas spp. in minimally processed Ready-to-Eat seafood. Microorganisms 2019, 7, 91. [CrossRef] [PubMed]

37. Amorim, A.M.; Nascimento, J.D. Acinetobacter: An underrated foodborne pathogen? J. Infect. Dev. Ctries. 2017, 11, 111-114. [CrossRef] [PubMed]

38. Selleck, E.M.; Van Tyne, D.; Gilmore, M.S. Pathogenicity of Enterococci. Microbiol. Spectr. 2019, 7. [CrossRef]

39. Bondi, M.; Laukova, A.; de Niederhausern, S.; Messi, P.; Papadopoulou, C.; Economou, V. Controversial aspects displayed by Enterococci: Probiotics or pathogens? Biomed. Res. Int. 2020, 2020, 9816185. [CrossRef] [PubMed]

40. Giraffa, G. Enterococci from foods. FEMS Microbiol. Rev. 2002, 26, 163-171. [CrossRef]

41. Verraes, C.; Van Boxstael, S.; Van Meervenne, E.; Van Coillie, E.; Butaye, P.; Catry, B.; de Schaetzen, M.A.; Van Huffel, X.; Imberechts, H.; Dierick, K.; et al. Antimicrobial resistance in the food chain: A review. Int. J. Environ. Res. Public. Health 2013, 10, 2643-2669. [CrossRef] [PubMed]

42. Wang, Y.T.; Lin, Y.T.; Wan, T.W.; Wang, D.Y.; Lin, H.Y.; Lin, C.Y.; Chen, Y.C.; Teng, L.J. Distribution of antibiotic resistance genes among Staphylococcus species isolated from ready-to-eat foods. J. Food Drug. Anal. 2019, 27, 841-848. [CrossRef] [PubMed]

43. Lee, L.; Savage, V.M.; Yeh, P.J. Intermediate levels of antibiotics may increase diversity of colony size phenotype in bacteria. Comput. Struct. Biotechnol. J. 2018, 16, 307-315. [CrossRef]

44. Devlieghere, F.; Vermeiren, L.; Debevere, J. New preservation technologies: Possibilities and limitations. Int. Dairy J. 2004, 14, 273-285. [CrossRef]

45. Antonio, C.M.; Abriouel, H.; López, R.L.; Omar, N.B.; Valdivia, E.; Gálvez, A. Enhanced bactericidal activity of enterocin AS-48 in combination with essential oils, natural bioactive compounds and chemical preservatives against Listeria monocytogenes in ready-to-eat salad. Food Chem. Toxicol. 2009, 47, 2216-2223. [CrossRef]

46. Ben-Fadhel, Y.; Maherani, B.; Aragones, M.; Lacroix, M. Antimicrobial properties of encapsulated antimicrobial natural plant products for Ready-to-Eat carrots. Foods. 2019, 8, 535. [CrossRef]

47. European Commission. Regulation on the hygiene of foodstuffs, 852/2004/EC. Off. J. L 2004, $139,54$. 